\title{
SCOPE OF TAINT UNDER THE EXCLUSIONARY RULE OF THE FIFTH AMENDMENT PRIVILEGE AGAINST SELF-INCRIMINATION
}

In the 1963 Term the United States Supreme Court handed down two landmark decisions affecting the privilege against self-incrimination. ${ }^{1}$ In Malloy v. Hogan the Court held that "the Fifth Amendment's exception from compulsory self-incrimination is also protected by the Fourteenth Amendment against abridgement by the States. . . ."2

On the same day the Supreme Court delivered a second opinion which was a logical consequence of the Malloy decision. In Murphy v. Waterfront Comm' ${ }^{3}$ the Court extended the protection of the fifth amendment ${ }^{4}$ to those cases in which the privilege against self-incrimination was claimed because of the possibility of prosecution in a foreign jurisdiction. ${ }^{5}$ Prior to Murphy the so-called "dual sovereignties" rule dictated that a witness in one jurisdiction could not claim his privilege with respect to a foreign crime because "the powers of the General Government, and of the State, although both exist and are exercised within the same territorial limits, are yet separate and distinct sovereignties, acting separately and independently of each other, within their respective spheres. . . " 6 In overturning this rule, the Murphy Court reasoned that it would defeat the policies of the privilege against self-incrimination to allow a witness who now has the privilege under both state and federal jurisdictions to be " "whipsawed into incriminating himself under both state and federal law," " 7 a possibility made particularly acute by widespread interjurisdictional cooperation in law enforcement. Murphy therefore concluded that "the constitutional privilege against self-incrimination protects a state witness against incrimination under federal as well as state law and a federal

1 Malloy v. Hogan, 378 U.S. 1 (1964); Murphy v. Waterfront Comm'n, 378 U.S. 52 (1964).

2378 U.S. at 6.

3378 U.S. 52 (1964).

4 Hereinafter, references to the fifth amendment refer only to the particular clause in question-the privilege against self-incrimination.

5 "Foreign" is used to characterize any jurisdiction, state or federal, outside of the compelling jurisdiction.

6 Ableman v. Booth, 62 U.S. (21 How.) 506, 516 (1858). See generally Grant, Federalism and Self-Incrimination: I \& II, 4 U.C.L.A.L. Rev. 549 (1957); 5 U.C.L. A.L. REv. 1 (1958); Kroner, Self Incrimination: The External Reach of the Privilege, 60 Colum. L. REv. 816 (1960). The case law based upon the dual sovereignties rule is best exemplified by United States v. Murdock, 284 U.S. 141, 149 (1931) (federal government can compel testimony incriminating under state law); Feldman v. United States, 322 U.S. 487, 492 (1944) (federal courts can admit evidence compelled under a state grant of immunity); Knapp v. Schweitzer, 357 U.S. 371, 379 (1958) (state can compel testimony incriminating under federal law).

7378 U.S. at 55 (quoting from the dissenting opinion of $\mathrm{Mr}$. Justice Black in Knapp v. Schweitzer, supra note 6, at 385). 
witness against incrimination under state as well as federal law." 8 More narrowly, the Court held that a witness before the New York-New Jersey Waterfront Commission was entitled to remain silent because of his justifiable fear, in light of the existing law, that anything he said might be incriminating under federal law. ${ }^{9}$ In what might be considered a prospective pronouncement of law, the Court further indicated that a state witness may be compelled in the future to testify under an appropriate state immunity statute without there being any violation of his privilege against selfincrimination, since the federal government will not be permitted to prosecute that witness if it must rely on his testimony or on any of its fruits. ${ }^{10}$ In establishing this rule, the Court declared that a prosecuting jurisdiction must show that its prosecution is based upon sources independent of the substance of the witness' testimony: "Once a defendant demonstrates that he has testified, under a state grant of immunity, to matters related to the federal prosecution, the federal authorities have the burden of showing that their evidence is not tainted by establishing that they had an independent, legitimate source for the disputed evidence." 11

The requirement of such a showing would seem to be the best possible resolution of the interests of the individual, the investigating jurisdiction, and the prosecuting jurisdiction. Starting from the basic premise that the privilege against self-incrimination extends across jurisdictional lines, the Court could have adopted any one of four rules: the witness is entitled to remain silent, ${ }^{12}$ the investigating jurisdiction may compel testimony but, if it does, the witness is immune from prosecution in that or any other jurisdiction, ${ }^{13}$ the witness may be compelled to testify, but the testimony may not be used by any jurisdiction in a prosecution of that witness, or the witness may be compelled to testify, but his testimony and its fruits may be excluded in any future prosecution. Had the Court chosen the right to remain silent as the vehicle of the privilege, the investigative aspect of state or federal law enforcement might have been irreparably damaged because of the impossibility of compelling testimony, the latter being an important means of securing legislative information. Had the Court selected the compulsion-immunity resolution of the conflict, the prosecuting aspect of a jurisdiction's law enforcement would have been severely hindered. Had the Court chosen exclusion of the testimony only, and not of its fruits, the constitutional rights of the individual would have been

8378 U.S. at 77-78.

Id. at 79.

10 Id. at $79 \&$ n.18.

$11 I d$. at 79 n.18.

12 The traditional form of the fifth amendment privilege is the right to remain silent: "[N]or shall ; $\cdot$ [he] be compelled in any criminal case to be a witness against himself. ... U.S. CoNST. amend. V.

13 This resolution would be similar in effect to the various immunity statutes. For a list of such federal statutes see Note, The Federal Witness Immunity Acts in Theory and Practice: Treading the Constitutional Tightrope, 72 Y YIE L.J. 1568, 1611-12 (appendix A) (1963). 
sacrificed. On the other hand, the Court's decision to choose the more complete compulsion-exclusion method of effectuating the privilege against self-incrimination safeguards the individual's rights and leaves interested jurisdictions free to investigate crime, while at the same time leaving other potential prosecuting jurisdictions in the same position in which they would have been had the witness been allowed to remain silent.

The Murphy resolution, however, does pose a possible threat to effective law enforcement. A jurisdiction which decides to compel testimony [J-1] has made an election between information and prosecution, and has chosen the former. A potential prosecuting jurisdiction [J-2], on the other hand, has had no voice in this determination yet will be affected thereby to the extent that it will be required to forego prosecution when it cannot meet its burden of proving that its prosecution was in no way based upon the testimony compelled in J-1. Some commentators believe that the burden placed upon the prosecution to show that its case is based upon independent sources of information would greatly hinder prosecutorial efforts. ${ }^{14}$ The major aspect of this problem is the scope of taint: How independent or how attenuated from the original "contaminated" source (the compelled testimony elicited in J-1) must the relevant source be. It is only in the answer that the Court formulates to this question that any actual hindrance to effective law enforcement will become discernible.

The doctrine of taint is one element of the rule of exclusion. This rule provides that evidence which has been seized illegally ${ }^{15}$ must be excluded from use in any trial of the defendant whose constitutional rights have been violated. The doctrine of taint extends this rule by declaring that other evidence (characterized as "fruit of the poisonous tree") discovered by use of the originally illegally seized evidence must likewise be excluded. ${ }^{10}$ The exact breadth and scope of taint in the area of self-incrimination are as yet unclear. As it relates to illegal searches and seizures, coerced confessions, wiretapping and other forms of primary illegality, ${ }^{17}$ the case law in this area indicates a judicial reluctance to follow to its logical conclusion the labeling of evidence as fruit of a poisonous tree ${ }^{18}$ - a tendency which

14 See, e.g., Comment, Self-Incrimination and the States: Restriking the Balance, 73 Y ALE L.J. 1491, 1494 (1964).

15 The rule also applies to coerced confessions. The Supreme Court, however, has not passed on the question of taint as it applies to this area.

16 The doctrine that poisonous fruit spreads further than the product of the initial illegality has its roots in Silverthorne Lumber Co. v. United States, 251 U.S. 385 (1920). "The essence of a provision forbidding the acquisition of evidence in a certain way is that not merely evidence so acquired shall not be used before the Court but that it shall not be used at all. . . " Id. at 392; accord, Nardone v. United States, 308 U.S. 338 (1939).

17 Before Murphy, all the exclusionary rules had been the outgrowth of primary illegalities such as those mentioned in text. The Murphy exclusionary rule, however, operates in situations of court sanctioned "seizures." See 378 U.S. at 79.

18 See, e.g., Smith v. United States, 324 F.2d 879 (D.C. Cir. 1963), cert. denied, 377 U.S. 954 (1964); Wayne v. United States, 318 F.2d 205 (D.C. Cir.), cert. denied, 375 U.S. 860 (1963); Benetti v. United States, 97 F.2d 263 (9th Cir. 1938); United States v. Avila, 227 F. Supp. 3 (N.D. Cal. 1963); Kamisar, Illegal Searches or Seizures and Contemporaneons Incriminating Statements: A Dialogue on a Neglected Area of Criminal Procedure, 1961 U. ILL. L.F. 78, 95. 
holds within narrow bounds the distance from which the taint spreads out from the primary illegality. In other words, the requirement that evidence used in prosecutions have an origin independent of the primary illegality is to a certain extent disregarded. Courts have applied tests which ask whether the evidence could or would have been discovered through independent legal means, rather than seeking to discover whether the evidence did in fact have an independent origin. ${ }^{10}$ However, there is reason to believe that in the area of the privilege against self-incrimination it will be more likely for fruit to be found poisonous than is presently the case in the area of primary illegality. This observation follows from the fact that in the area of primary illegality the exclusionary rule is based principally upon the concept of deterrence, while in the area of the privilege against selfincrimination the rule is intended to prevent harm to the particular individual..$^{20}$

The thrust of the exclusion cases dealing with primary illegality, most of which have been concerned with search and seizure, is that the only way to enforce the constitutional rights involved is to exclude the fruits of violations of these rights. This conclusion seems evident from the fact that the Supreme Court in Wolf $v$. Colorado, ${ }^{21}$ while recognizing that the fourth amendment applied to the states, ${ }^{22}$ did not consider exclusion a necessary part of that amendment. ${ }^{23}$ Only in 1961, when no other means seemed sufficient to protect the constitutional right in issue, did the Supreme Court in Mapp v. Ohio ${ }^{24}$ resort to an interpretation of the fourth amendment which required state courts to exclude illegally seized evidence. Even though $M a p p$ did not purport to rest its holding upon a factual determination that there were no other means available to protect the constitutional right, the explicit recognition in the opinion that there were no other effective means of deterrence to enforce the right ${ }^{25}$ suggests that this was the underlying basis of the decision. ${ }^{26}$ References to "deterrence" and "enforcement" continually appear throughout the cases ${ }^{27}$ and articles ${ }^{28}$ in this area. Thus it would seem that this exclusionary rule is, in a manner of speaking, not the substance of the right itself but the means by which

19 See Maguire, How To Unpoison the Frnit-The Fourth Amendment and the Exclusionary Rule, 55 J. CRrar. L., C. \& P.S. 307, 313 (1964).

20 See Barrett, Exclusion of Evidence Obtained by Illegal Searches-A Comment on People vs. Cahan, 43 CALIF. L. Rev. 565, 579-82 (1955).

21338 U.S. 25 (1949).

$22 I d$. at $27-28$.

$23 I d$. at 33 .

24367 U.S. 643 (1961).

$25 \mathrm{Id}$. at 652-53.

26 See Bender, The Retroactive Effect of an Overruling Constitutional Decision: Mapp v. Ohio, 110 U. PA. L. Rev. 650, 661 (1962).

27 E.g.; Linkletter v. Walker, 381 U.S. 618 (1965) ; Mapp v. Ohio, 367 U.S. 643 (1961); Weeks v. United States, 232 U.S. 383 (1914).

28 E.g., Bender, supra note 26, at 661; Traynor, Mapp v. Ohio at Large in the Fifty States, 1962 Duke L.J. 319, 334. 
the constitutional right is enforced. ${ }^{29}$ The exclusion of such evidence can be said to be derivative; it is remedial, a means to enforce the primary aspect of the right-that illegal searches and seizures should not take place.

Viewing the primary function of the exclusionary rule as one of deterrence and looking at the rule in connection with its logical outgrowththat Mapp shall not be applied retroactively ${ }^{30}$-one is forced to the conclusion that the right of privacy (freedom from illegal search and seizure) is, in terms of the exclusionary rule, a right to be looked at as it relates to society as a whole and not to the particular defendant in question. ${ }^{31}$ Exclusion is not intended to place the defendant in the position in which he would have been but for the illegal search and seizure, but is designed instead to curb police activity in general as it violates the fourth amendment. If the wrong done to the particular defendant had to be righted, it would then follow that $M a p p$ must be applied retroactively. That Mapp was not so applied suggests that the remedying of a particular defendant's rights is not the reason for exclusion. As Professor Bender has said:

If Mapp v. Ohio must be applied generally to previous trials [Professor Bender feels it should not], it must be because its rule is intended directly to relieve those who have actually suffered an unconstitutional search, not just to provide an indirect means of assuring general privacy through the removal of an incentive to police to act improperly. It seems safe to say that the exclusion of evidence is not a constitutionally required state compensation for the victims of an unconstitutional search. . . . ${ }^{32}$

As it relates to the interjurisdictional area of the privilege against selfincrimination, the exclusionary rule would seem to be both a more integral part of the privilege and more closely related to the rights of the particular defendant. ${ }^{33}$ The exclusionary rule in this area does not implement the

29 But see Allen, Federalism and the Fourth Amendment: A Requiem for Wolf, 1961 Supreme Court Rev. 1, 35.

30 Linkletter v. Walker, 381 U.S. 618 (1965).

31 "The objective of the exclusionary rule is certainly not to compensate the defendant for the past wrong done to him any more than it is to penalize the officer for the past wrong he has done. The emphasis is forward." Traynor, supra note 28 , at 335. And again: "Such a focus to ferret out some violated right of the defendant suggests, though perhaps unintentionally, that the objective of the exclusionary rule is to make amends to the defendant. What should be of primary concern is not the grievances of selected guilty defendants such as land-owners or the gentry of invitees, but the grievousness of official lawlessness." Ibid.; accord, People v. Cahan, 44 Cal. 2d 434, 439, 282 P.2d 905, 907 (1955); Allen, The Wolf Case: Search and Seizure, Federalism and the Civil Liberties, 45 ILL. L. Rev. 22 (1950).

32 Bender, supra note 26, at 663-64.

33 In discussing the question of the retroactivity of Mapp, Professor Bender distinguished between a simple fourth amendment violation and one compounded by a fifth amendment problem: "There is one situation in which the exclusion of evidence has always been deemed to be constitutionally required without exploration of the need for police deterrence: when its use would amount to unconstitutional selfincrimination. .. ". Id. at 664-65.

In Tehan v. United States ex rel. Shott, 34 U.S.I. WEeK 4095, 4098 (U.S. Jan. 19 , 1966), which refused to apply retroactively the holding in Griffin v. California, 
right of silence but rather forms a substitute for it. It tells the witness that he must give information to the appropriate authorities, but that his disclosures will not harm him since he will be placed in the same position he would have been in had he invoked his constitutional privilege against selfincrimination and it had been honored. As in the case of immunity statutes, a substitute for the privilege, or, in the Murphy situation, that which might be considered a reformulation of the privilege, must be at least as broad as the privilege itself. ${ }^{34}$ In Counselman $v$. Hitchcock, ${ }^{35}$ a case in which an immunity statute was held unconstitutional, the Supreme Court noted that:

It [the immunity statute in question] could not, and would not, prevent the use of his testimony to search out other testimony to be used in evidence against him . . . , in a criminal proceeding in such a court. It could not prevent the obtaining and the use of witnesses and evidence which should be attributable directly to the testimony he might give under compulsion, and on which he might be convicted, when otherwise, and if he had refused to answer, he could not possibly have been convicted. ${ }^{3 \mathrm{~B}}$

Because the fifth amendment exclusionary rule is more closely linked to the rights of the particular defendant and is a more integral part of the privilege than is the fourth amendment exclusionary rule, courts should not have the same flexibility in applying it. To fulfill faithfully the constitutional requirement of coextensive breadth, J-2 must be required to use only that which is in no way casually related to the compelled testimony. The evidence used must have an entirely independent origin, not the mere possibility that it could have had such an origin or even that it would have had such an origin.

The existence of three variations of the poisonous fruit doctrine in the Supreme Court also bears on this conclusion. The first of these variations came in Silverthorne Lumber Co. v. United States. ${ }^{37}$ In discussing the prohibition of the use of tainted evidence, the Court in that case said:

380 U.S. 609 (1965), that comment by state prosecutors or judges on defendant's failure to take the stand violated the fifth amendment, the Supreme Court stated that "the basic purposes that lie behind the privilege against self-incrimination do not relate to protecting the innocent from conviction, but rather to preserving the integrity of a judicial system in which even the guilty are not to be convicted unless the prosecution "shoulder the load." Even if this view is accepted, it is inapplicable to the interjurisdictional area of the privilege, where the exclusionary rule has as its sole purpose the restoration of defendant to the position he would have been in had his testimony not been compelled. See text following this note. It is only because of the protection afforded the defendant by the exclusionary rule that the Murphy Court was willing to permit compulsion of testimony.

34 Counselman v. Hitchcock, 142 U.S. 547, 585 (1892).

35142 U.S. 547 (1892).

$36 \mathrm{Id}$. at 564. (Emphasis added.)

37251 U.S. 385 (1920). 
"Of course this does not mean that the facts thus obtained become sacred and inaccessible. If knowledge of them is gained from an independent source they may be proved like any others, but the knowledge gained by the Government's own wrong cannot be used by it in the way proposed. .. ." 38 This may be characterized as the "independent source" test.

Some nineteen years later the Supreme Court articulated what appears to be a second variation of the doctrine. In Nardone v. United States, ${ }^{39}$ after reiterating the "independent source" rule of Silverthorne, the Court went on to observe: "In practice this generalized statement may conceal concrete complexities. Sophisticated argument may prove a causal connection between information obtained through illicit wire-tapping and the Government's proof. As a matter of good sense, however, such connection may have become so attenuated as to dissipate the taint . . . " 40 This second test redefines the "independent source" test by expanding it. Its very acceptance of the concept of "attenuation" relaxes the original, strict test set forth in Silverthorne, since that concept concedes the existence of taint in admissible evidence but argues that it has become dissipated.

The third and most recent variation of the taint test was enunciated by the Supreme Court in 1963 in Wong Sun v. United States. ${ }^{41}$ The Court stated:

We need not hold that all evidence is "fruit of the poisonous tree" simply because it would not have come to light but for the illegal actions of the police. Rather, the more apt question in such a case is "whether, granting establishment of the primary illegality, the evidence to which instant objection is made has been come at by exploitation of that illegality or instead by means sufficiently distinguishable to be purged of the primary taint. . . ." 42

This test goes far beyond the previous two by its acceptance of the hypothesis that evidence may be admitted even though it might never have come to the fore but for the original illegality. ${ }^{43}$

38 Id. at 392.

39308 U.S. 338 (1939).

$40 \mathrm{Id}$. at 341 .

41371 U.S. 471 (1963).

$42 I d$. at $487-88$.

43 Nardone does not go as far as Wong Snn because it does not articulate the proposition that evidence may be admissible even if it would not have been exposed but for the primary illegality. Thus, Nardone can be restricted to instances in which the evidence used was derived from information obtained from an illegal search and seizure, but which would have been obtained irrespective of that search through another, legal channel of information.

For a brief discussion of these three tests in the context of an analysis of Wong Sun, see Broeder, Wong Sin v. United States: $A$ Study in Faith and Hope, 42 NER. L. REv. 483, 545 (1963). 
The Supreme Court's articulation of an unqualified "independent source" test in Murphy would seem to be an implicit rejection of its two most recent tests and a reaffirmation of the original Silverthorne test. This conforms to the analysis that views the fifth amendment exclusionary rule as stricter than the exclusionary rule which sprang from the fourth amendment. Because it is more strict, the fifth amendment exclusionary rule is likely to have a more inhibiting effect upon law enforcement than the Mapp decision had. This, however, would seem a necessary result in light of the different purposes served by the exclusion of evidence under the fourth and fifth amendments. 